Volume: 11 Issue: 2 Year: 2014

\title{
Validity and reliability study of Quality of School Work Life (QSWL) scale
}

\author{
Abdurrahman Ilgan ${ }^{1}$ \\ Atakan Ata ${ }^{2}$ \\ Sally J. Zepeda ${ }^{3}$ \\ Oyku Ozu-Cengiz ${ }^{4}$
}

\begin{abstract}
QSWL in psychosocially manner defined as "the effect of the workplace on satisfaction with the job, satisfaction in non-work life domains, and satisfaction with overall life, personal happiness, and subjective well-being". This research aimed to develop a valid and reliable measurement instrument that is designed to measure QSWL based on literature, expert and practitioner teachers' knowledge. 784 teachers were participant of this research. Draft scale included 30 items of the instruments. To validate the scale exploratory factor analysis followed by confirmatory analysis. Exploratory factor analysis revealed that QSWL scale is composed of five dimensions. Confirmatory analysis revealed that $\chi^{2} /$ sd ratio were in intermediate level, value of RMSEA and RMR were in represents of acceptable fit whereas GFI and AGFI indexes were in weak level and finally NNFI and CFI were in sufficient value. Cronbach's Alpha coefficient values for QSWL subdimensions were ranged between .62 and .85 whereas this value was .87 for composite scale. Consequently, this newly developed scale is a valid and reliable instrument that serves to measure and describe schools' quality of work life.
\end{abstract}

Keywords: Quality; School life; Quality of school work life; Scale development; Validity and reliability

\section{Introduction and Literature Review}

Although the concept of the QWL did not appear until near the end of the 1960s (Baleghizadeh \& Gordani, 2012), it is possible to see that some companies exhausted various efforts to improve conditions for their workers as early as 1800s (Bindu \& Yashika, 2014; Martel \& Dupuis, 2006).

\footnotetext{
Ph.D., Duzce University, College of Education, Department of Educational Sciences, abdurrahmanilgan@,duzce.edu.tr

${ }^{2}$ Ph.D. student, University of Georgia, College of Education, Department of Lifelong Education, Administration, and Policy, ata@uga.edu

3 Ph.D., University of Georgia, College of Education, Department of Lifelong Education, Administration, and Policy, szepeda@uga.edu

${ }^{4}$ Ph.D., Celal Bayar University, College of Education, Department of Psychological Counseling and Consultation, oykuozu@gmail.com
} 
Ilgan, A., Ata, A., Zepeda, S. J., \& Ozu-Cengiz, O. (2014). Validity and reliability study of Quality of School Work Life (QSWL) scale. International Journal of Human Sciences, 11(2), 114-137. doi: 10.14687/ijhs.v11i2.2866

Triggered by the postwar economy, industrialization increased, and most organizations chose to adopt Taylor's method (Scientific Management) by the end of 1960s. Taylor's method was initiated by an American mechanical engineer, Frederick Winslow Taylor, who aimed to improve industrial efficiency by breaking work assignments into simple tasks for workers. This method provided a great deal of efficiency for companies, but dehumanization of work became an issue.

Attempts to develop work organizations first took place in Europe, but they were not wellorganized efforts (Davis \& Cherns, 1975). Irving Bluestone, an American General Motors employee was first to use the expression "Quality of Work Life" in a program that allowed workers to play an active role in making decisions concerning their working conditions (Bindu \& Yashika, 2014; Goode, 1989; Martel \& Dupuis, 2006). Job dehumanization, various problems such as safety, compensation, and work-place conditions that often led to employee alienation forced managers to reconsider methods used in workplaces. An international conference on QWL was held in 1972 in Toronto (Bindu \& Yashika, 2014). The general conclusion was to recognize the necessity of coordinating efforts by the researchers, and within a year the International Council for the Quality of Working Life was formed to encourage research and to produce information on mental health at work (Bindu \& Yashika, 2014; Martel \& Dupuis, 2006).

It is difficult to pin-point an exact and universally-accepted definition for QWL (Bindu \& Yashika, 2014; Hannif, Burgess, \& Connell, 2008). Walton (1973), one of the early researchers of QWL, asserted that the concept suggested comprehensiveness and was broader than the aims of the unionization movement, labor laws, or equal employment struggles. The eight conceptual categories Walton (1973) proposed are often still used to measure QWL. These categories are

1. Adequate and fair compensation: Walton (1973) claimed that the primary motivation for employment was earning a living, thus equal payment for equal work is important.

2. Safe and healthy working conditions: Workers should not be exposed to physical conditions that are dangerous or irrational hourly arrangements.

3. Immediate opportunity to use and develop human capacities: Dehumanization of work calls a necessity for some qualities in human development and these qualities are autonomy, multiple skills, perspective, and planning. 
Ilgan, A., Ata, A., Zepeda, S. J., \& Ozu-Cengiz, O. (2014). Validity and reliability study of Quality of School Work Life (QSWL) scale. International Journal of Human Sciences, 11(2), 114-137. doi: 10.14687/ijhs.v11i2.2866

4. Future opportunity for continued growth and security: This category suggests career opportunities. Most workers lose interest in their professional work with time, so they no longer invest in their career pursuits, and increase the sterility of their work lives.

5. Social integration in the work organization: It is important to create an atmosphere in which there is a sense of belongingness to the organization by the employees.

6. Constitutionalism in the work organization: A worker is affected by many decision that are made in the organization, so various aspects of constitutionalism (privacy, free speech, equity, and due process) are key elements in providing higher quality of work life.

7. Work and total life space: Walton (1973) expressed the relationship of work to the total life space with the concept of balance. An unbalanced role of work can have negative effects on other spheres of worker's life.

8. The social relevance of work life: The socially beneficial roles or the socially injurious effects of the organization cause employees to criticize the value of their work and eventually their roles in the organization.

The concept of QWL changed during the 1980s and was defined as a way of thinking about people, work, and organizations whose distinctive elements are (1) a concern about the impact of work on people as well as on organizational effectiveness, and (2) the idea of participation in organizational problem solving and decision making (Nadler \& Lawler III, 1984). Mirvis and Lawler III defined it as an economic, social, and psychological relationship between an organization and its employees represented as $Q W L=f(O, E)$ where $O$ represents characteristics of the work and work environment in an organization and E represents their impact on employees' welfare and wellbeing. According to this definition, organizations must provide a safe working environment, fair compensation, equal employment opportunities, and opportunities for job mobility and advancement. Moreover, supervision, evaluation, and rewards that motivate and develop personnel are critical in supporting QWL (Mirvis \& Lawler III, 1984). Similarly, Robbins (1989, p. 207) defined QWL as "a process by which an organization responds to employee needs by developing mechanisms to allow them to share fully in making the decisions that design their lives at work."

Since the mid-1990s, work-family efforts have begun to focus on creating a supportive culture and effective work practices (Friedman, Rimsky, \& Johnson, 1996). The interest in quality of work life 
Ilgan, A., Ata, A., Zepeda, S. J., \& Ozu-Cengiz, O. (2014). Validity and reliability study of Quality of School Work Life (QSWL) scale. International Journal of Human Sciences, 11(2), 114-137. doi: 10.14687/ijhs.v11i2.2866

has increased in importance to the organization and human resources in terms of the performance of the organization and employee job satisfaction (Akdere, 2006; Gayathiri \& Ramakrishnan, 2013). People began to know more about quality of work when the United Auto Workers and General Motors introduced a quality of work life program during their work reform (Beer et al., 1985). In recent years, QWL is more psychosocially defined as "the effect of the workplace on satisfaction with the job, satisfaction in non-work life domains, and satisfaction with overall life, personal happiness, and subjective well-being" (Sirgy, Efraty, Siegel, \& Lee, 2001, p. 242). Thus, today it is believed that QWL affects not only a working person's satisfaction with the job but also other domains of his/her life, such as family life, leisure activities, social life, and financial status (Akdere, 2006; Danna \& Griffin, 1999; Zhao, Sun, Cao, Li, Duan, Fan, \& Liu, 2012). Quality of work-life affects employee turnover and retention (Zhao et al., 2012) and holds implications for individual commitment to the position and the company.

Hannif et al. (2008) offer that from their analysis, the literature on QWL can be divided into "three camps" or areas of emphasis-1) focus on job satisfaction, 2) the subjective well-being of the employee, or 3) a "dynamic, multi-dimensional construct that incorporates any number of measures" surrounding employee well-being (p. 274). Given globalization, changes in labor markets, and rapidly changing contexts flattened by technology, it is important to understand QWL in the private and public sectors.

QWL has been studied across a range of disciplines. For example, Zhao et al. (2012) examined affective commitment of nurses related to the intention to continue employment while Hsu and Kernohan (2005) examined the dimensions that support the overall quality of QWL for nurses in Taiwan as a means to develop a framework for further research. In another study about QWL and nurses in Nigeria, Awosusi (2010) found that although nurses were satisfied with their work, there were QWL issues that hospital administrators needed to pay particular attention to issues related to promotion and pay. As fields change and evolve, the study of QWL needs to be malleable enough to examine the principles, constructs, frameworks, and understandings of the issues that encompass quality of work-life issues such as in studying call-center workers (Hannif et al., 2008). 
Ilgan, A., Ata, A., Zepeda, S. J., \& Ozu-Cengiz, O. (2014). Validity and reliability study of Quality of School Work Life (QSWL) scale. International Journal of Human Sciences, 11(2), 114-137. doi: 10.14687/ijhs.v11i2.2866

Although the QWL measurement for this study was adopted from Walton's (1973) categories, it can be tailored for educators and educational settings. In general, several studies have shown that QWL has a positive relationship with other variables within the organization

Jofreh, Yasini, Dehsorkhi, \& Hayat, 2013; Lu, While, \& Barriball, 2007; Spector, 1997; Tsai, Yen, Huang, \& Huang, 2007), but educators have different primary reasons for their choice of occupations such as making a change in student's lives or job security compared to employees in other sectors with reasons such as higher compensation or career opportunities.

Quality of School Work Life (QSWL) shows great promise for understanding the quality of work life for teachers, administrators, and the communities in which they work. Only in the past few years have researchers began to view QSWL as a viable construct for understanding the complexities of schools to possibly inform policy and practice. The following studies are offered for illustrative purposes to show the range in which studies about QWL have been used in the educational context. For example, Emadzadeh, Khorasani, and Nematizadeh (2012) examined QWL issues of primary school teachers, and Darabi, Mehdizadeh, Arefi, and Ghasemi (2013) examined QWL and job satisfaction of high school teachers in Kermanshah. Baleghizadeh and Gordani (2012) examined QWL in secondary school English as foreign language (EFL) teachers in Tehran, Iran, and they reported that QWL would more than likely increase through more professional growth opportunities, increased input into decision-making, and a more purposeful way of promoting human capital by using their talents to foster collaboration across the various schools they serve.

These studies are promising examples of research about QWL for educational organizations; however, there is a need for a more purposeful examination of QWL within educational studies (Day, Elliot, \& Kington, 2005; Jofreh et al., 2013). The present study hopes to offer to the literature and research base by expanding our understandings of QWL in educational settings.

\section{Purpose of the research}

This research aimed to develop a valid and reliable measurement instrument that is designed to measure QSWL based on literature, expert and practitioner teachers' knowledge. 
Ilgan, A., Ata, A., Zepeda, S. J., \& Ozu-Cengiz, O. (2014). Validity and reliability study of Quality of School Work Life (QSWL) scale. International Journal of Human Sciences, 11(2), 114-137. doi: 10.14687/ijhs.v11i2.2866

\section{Population and Sampling}

Sample size is an issue that has received considerable discussion in the literature. Larger sample sizes ensure the reliability of results in research, yet it is not easy to reach to a great number of participants. DeVellis (2003) suggested that there were two central risks with using too few participants: (a) Patterns of covariation may not be stable, because chance can substantially influence correlations among items when the ratio of participants to items is relatively low; and (b) the development sample may not adequately represent the intended population. Gorsuch (1983) also proposed guidelines for minimum ratios of participants to items (5:1 or 10:1), which has been widely cited in counseling psychology research. Although there are researchers who hold various standpoints about the size of sample size (Tabachnic \& Fidell, 2001; Velicer \& Fava, 1998), Worthington and Whittaker (2006, p.817) proposed four situations regarding sample size based on the literature: (a) Sample sizes of at least 300 are generally sufficient in most cases, (b) sample sizes of 150 to 200 are likely to be adequate with data sets containing communalities higher than .50 or with 10:1 items per factor with factor loadings at approximately $|.4|$, (c) smaller samples sizes may be adequate if all communalities are .60 or greater or with at least 4:1 items per factor and factor loadings greater than $|.6|$, and (d) samples sizes less than 100 or with fewer than 3:1 participant-toitem ratios are generally inadequate.

The target population of the study $(\mathrm{N}=800)$ included primary and secondary public school teachers working in different cities of Turkey during 2012-2013 academic year. Participants to survey of the study were from various cities (Ankara, İzmir, Manisa, Mardin, Isparta and Duzce), and as these cities are geographically located throughout the country, they are highly capable of representing the whole picture of Turkey. Participating teachers were selected using cluster sampling. The lists of schools and school districts were obtained from the provincial offices of education. Upon formal permission of provincial offices of education, the surveys were administered in 80 schools. In total, 900 paper surveys were administered in 6 cities; to ensure desired sample size, the number of distributed surveys was higher than the targeted sample size. The return rate for the survey was high (87\%) yielding a total of 784 responses. It is possible to say that 784 participants to the survey of the research are enough to meet the conditions proposed by researchers who stated various standpoints regarding sample size in scale development studies (Gorsuch, 1983; Tabachnic \& Fidell, 2001; Velicer \& Fava, 1998; Worthington \& Whittaker, 2006). Table 1 displays the demographic information of the participants. 
Ilgan, A., Ata, A., Zepeda, S. J., \& Ozu-Cengiz, O. (2014). Validity and reliability study of Quality of School Work Life (QSWL) scale. International Journal of Human Sciences, 11(2), 114-137. doi: 10.14687/ijhs.v11i2.2866

Table 1. Demographic variables of participants

\begin{tabular}{|c|c|c|c|}
\hline Variable & Level & $\mathbf{N}$ & $\%$ \\
\hline \multirow{4}{*}{ Gender } & 1. Female & 421 & 53.7 \\
\hline & 2. Male & 359 & 45.8 \\
\hline & 3. No Response & 4 & .5 \\
\hline & 4. Total & 784 & 100 \\
\hline \multirow{4}{*}{ Marital Status } & 1. Married & 562 & 71.7 \\
\hline & 2. Single & 214 & 27.3 \\
\hline & 3. No Response & 8 & 1 \\
\hline & 4. Total & 784 & 100 \\
\hline \multirow{10}{*}{ Subject } & $\begin{array}{l}\text { 1. Classroom Teacher }\left(1^{\text {st }}, 2^{\text {nd }}, 3^{\text {rd }}, 4^{\text {th }}\right. \\
\text { grade) }\end{array}$ & 225 & 28,7 \\
\hline & 2. English Teacher & 70 & 8,9 \\
\hline & 3. Math & 67 & 8,5 \\
\hline & $\begin{array}{l}\text { 4. Science (Science Teacher, and } \\
\text { Information Technology }\end{array}$ & 82 & 10,5 \\
\hline & 5. Turkish Language and Literature & 87 & 11,1 \\
\hline & $\begin{array}{l}\text { 6. Social Sciences (History, Geography, } \\
\text { Social Studies, Religion) }\end{array}$ & 94 & 12,0 \\
\hline & $\begin{array}{l}\text { 7. School counsellor and preschool } \\
\text { teacher }\end{array}$ & 59 & 7,5 \\
\hline & 8. Physical education, art, music etc. & 81 & 10,3 \\
\hline & 9. No Response & 19 & 2.4 \\
\hline & 10. Total & 784 & 100 \\
\hline \multirow{8}{*}{$\begin{array}{l}\text { Age } \\
\text { Total }\end{array}$} & 1. $22-25$ years & 69 & 8.8 \\
\hline & 2. $26-30$ years & 237 & 30.2 \\
\hline & 3. $31-35$ years & 216 & 27.6 \\
\hline & 4. $36-40$ years & 113 & 14.4 \\
\hline & 5. $41-45$ years & 74 & 9.4 \\
\hline & 6.46 and more & 63 & 8.3 \\
\hline & 7. No Response & 12 & 1.5 \\
\hline & 8. Total & 784 & 100 \\
\hline
\end{tabular}

As shown in table 1, of the teachers participated in the research, a little over the half are female; the majority are married; subjects they teach are of variety; and most of them are younger than 40 . 
Ilgan, A., Ata, A., Zepeda, S. J., \& Ozu-Cengiz, O. (2014). Validity and reliability study of Quality of School Work Life (QSWL) scale. International Journal of Human Sciences, 11(2), 114-137. doi: 10.14687/ijhs.v11i2.2866

\section{Draft Measurement Instrument Development}

These steps were followed to create the pool of items in QSWL scale: First, 15 teachers who volunteered in this study were lectured about what QSWL is and what elements QSWL consists of. Second, the same participant teachers were asked to describe the factors that increase or decrease quality of work life in their schools. Improved by the help of literature review and opinions of experts on scale instruments specifically developed for industrial organizations, teachers' responses to closed and open ended questions made up the 30 items of the instruments -8 negative and 22 positive. Sub-dimensions were initially not projected in the draft measurement instrument, and statements in mixed negative and positive forms that were believed to represent the indicators of quality of work life were presented to elementary and middle school teachers. Measurement instrument is 5-point Likert type, and asks participants' level of agreement to the statements (indicators) regarding quality of school work life. Choices of the measurement instrument: Never, little, somewhat, much, and a great deal meaning that a high score obtained from the instrument represents high quality of school work life and a low score represents low quality of school work life.

\section{Data Analysis}

Factor analysis is a technique used to identify or confirm a smaller number of factors or latent constructs from a large number of observed variables (or items). There are two main categories of factor analysis (Kahn, 2006): (a) exploratory and (b) confirmatory. Exploratory Factor Analysis (EFA) assesses the construct validity during the initial development of an instrument. After developing an initial set of items, researchers apply EFA to examine the underlying dimensionality of the item set. Thus, they can group a large item set into meaningful subsets that measure different factors. The primary reason for using EFA is that it allows items to be related to any of the factors underlying examinee responses. As a result, the developer can easily identify items that do not measure an intended factor or that simultaneously measure multiple factors, in which case they could be poor indicators of the desired construct and eliminated from further consideration (Worthington \& Whittaker, 2006).

Additionally, the Kaiser-Meyer-Olkin (KMO) and Barlett's tests were used to verify the data's appropriateness for EFA and whether the data were sufficient (Worthington and Whittaker, 2006). The KMO statistic varies between 0 and 1 (Field, 2009). Hutcheson and Sofroniou (1999) 
Ilgan, A., Ata, A., Zepeda, S. J., \& Ozu-Cengiz, O. (2014). Validity and reliability study of Quality of School Work Life (QSWL) scale. International Journal of Human Sciences, 11(2), 114-137. doi: 10.14687/ijhs.v11i2.2866

recommend that $\mathrm{KMO}$ values between 0.5 and 0.7 are mediocare, values between 0.7 and 0.8 are good, values between 0.8 and 0.9 are great and values above 0.09 are superb. Bartlett's test of sphericity indicated that correlations between items were sufficiently for factor analysis and this value should be significant (Field, 2009).

Data normality distribution which is a base hypothesis of parametric statistics was also verified. Although there are different opinions on the observation counts regarding the appropriateness for the EFA, some scholars agreed that number of observation should not be less than 100-200 (Kline, 2005) or there should be 5-10 participants per item (Grimm and Yarnold, 1995). In this study, a total number of 784 observation counts were reached, and there were more than 10 participants per item that strongly verify the data's normality distribution.

\section{Findings}

In this section, findings regarding the QSWL instrument's EFA, CFA, reliability, and internal consistency are discussed

\section{Findings regarding $E F A$}

Table 2 displays the KMO and Barlett's tests' results of the QSWL instrument according to EFA.

Table 2. KMO and Barlett Tests results

\begin{tabular}{lll}
\hline Kaise-Mayer-Olkin Measure of Sampling Adequacy &, 911 \\
\hline Bartlett Testi & Ki-Kare & 2082,836 \\
& sd & 276 \\
p &, 000 \\
\hline
\end{tabular}

As table 2 displays, QSWL instrument's KMO value is very high and it is meaningful $(, 000)$ according to the Barlett's test. According to these results, it is possible to say that the data is appropriate for factor analysis (Hutcheson \& Sofroniou, 1999). Central tendency and variability measures were also checked to verify the data's normality distribution. What is important is that scores should not show excessive deviation more than normal (Büyüköztürk, 2002b). If the skewedness coefficient stays in \pm 1 boundary, it can be interpreted that scores don't show a remarkable deviation from their normal distribution. Skewedness and kurtosis coefficients of the 
Ilgan, A., Ata, A., Zepeda, S. J., \& Ozu-Cengiz, O. (2014). Validity and reliability study of Quality of School Work Life (QSWL) scale. International Journal of Human Sciences, 11(2), 114-137. doi: 10.14687/ijhs.v11i2.2866

analysis are respectively -,029 and -,038. Obtained scores are in \pm 1 boundary, and the data shows a distribution very akin to normal. Statements' factor loadings of the initial EFA in the measurement instrument development are given in table 3 .

Table 3. Initial Exploratory Factor Analysis Results on QSWL scale

\section{Statements}

\section{Dimensions}

16) Necessary opportunities are offered in order for me to do my job well.

\begin{tabular}{lllllll}
\hline 1 & 2 & 3 & 4 & 5 & 6 & 7
\end{tabular}

20) I can get assistance and contribution related to my work from administrators.

,812 - -,084, 096 -,064 154 -,108 -,136

19) Necessary assistance is offered for me to develop new skills at work.

9) I am treated equally by my superiors.

,790 - $-215,233,075 \quad-, 043-, 021-, 041$

11) The school has a proper setting for the activities of $, 748 \quad-, 036,015 \quad-, 158,268$-,123, 030
education and learning.

15) School administrators collaborate with teachers.

737 - 216, 175, 068 -,121,039 -090

18) I am pleased to be a member of this school.

,737 -,143-,000 - 283, -,003 28) Necessary opportunities are offered for me to ,732 -,038, 220 ,074,$- 037-, 205-, 014$
develop myself at work.

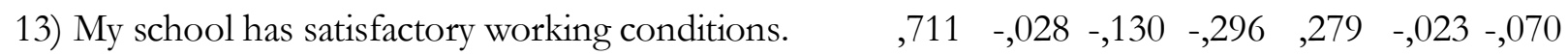

8) The school I work at has healthy working conditions. ,708 ,011 -,094 -

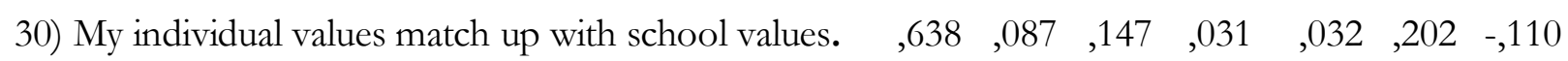

10) Necessary accommodation is offered for those who

want to build a career (such as graduate school or in-,611 -,042, 166 ,052 -,138-,292 -,096 service education).

22) I can make a healthy balance between home and ,566, 061 -,092, 075, 076, 300,
work.

23) I get along well with my colleagues.

27) There is trust issue among school personnel.*

497-,121-,095, 096 -,152, 484,

-,471, 101

5) My attendance to professional development opportunities such as open sessions, conferences, and,468 -,020 218 210 -,293 -,410, -,40 panels is encouraged.

1) I can talk with my superiors about my work problems directly and easily.

,450 - 234, 232

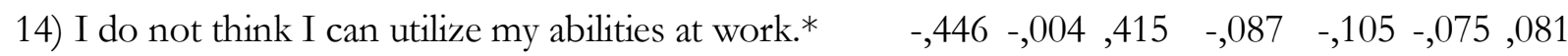

25) My work presents me interesting and different $441,389,174,335,129, \quad$, 124 experiences. 
Ilgan, A., Ata, A., Zepeda, S. J., \& Ozu-Cengiz, O. (2014). Validity and reliability study of Quality of School Work Life (QSWL) scale. International Journal of Human Sciences, 11(2), 114-137. doi: 10.14687/ijhs.v11i2.2866

21) I do not think the salary I get is enough for what I do for work.* $-, 323-, 566,278,230,251,114,0$

26) I find the opportunities for my health rights sufficient.

488 , 132

7) The salary I get is enough to follow up with academic publications such as books and journals in my field.

,437 461

17) The salary I get negatively affects my productiveness at work.*

$-, 446--, 450,430 \quad 034 \quad-, 007,064 \quad-, 221$

3) The salary I get positively affects my commitment to work.

301 398, 005 118 -,132, 265 -,077

29) I cannot defend my rights freely at work. * - 094

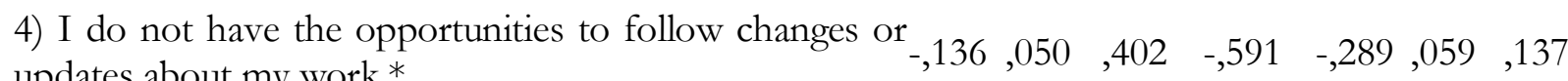
updates about my work.*

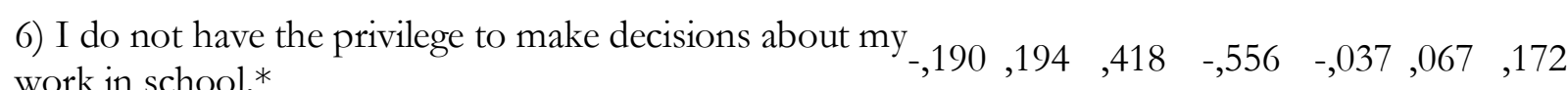
work in school.*

12) The number of classrooms in my school is not ${ }_{-, 255,002,223,465}^{,-363,048, ~-363, ~}$ enough for education and learning.*

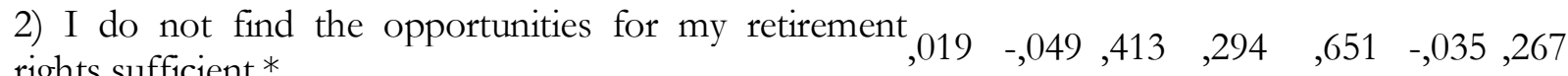
rights sufficient.*

24) I generally work isolated (individually; without any assistance)*

$-023,412,314,090,097$

* Negative items

In table 3, basic component analysis has resulted that some of the statements have very high factor loadings in the first dimension while some of them have high factor loadings in various dimensions. Because it was not possible to obtain a stable factor structure, vertical rotation by Varimax method was used. Two statements that are not in any of the dimensions (2 and 3), two statements that have high loadings in more than one dimensions (1 and 25), and two statements that don't make a dimension by themselves (24 and 30) were removed after three different analyses. Table 4 shows revised factor analysis results after Varimax method was applied.

Table 4. Final Exploratory Factor Analysis Results on QSWL scale

\section{Statements}

\section{Dimensions}

$\begin{array}{lllll}1 & 2 & 3 & 4 & 5\end{array}$

19) Necessary assistance is offered for me to develop new skills at 758 209 2005 , 235, , work. 
Ilgan, A., Ata, A., Zepeda, S. J., \& Ozu-Cengiz, O. (2014). Validity and reliability study of Quality of School Work Life (QSWL) scale. International Journal of Human Sciences, 11(2), 114-137. doi: 10.14687/ijhs.v11i2.2866 28) Necessary opportunities are offered for me to develop myself ,751, 174, 167, 123 -,064
at work. 20) I can get assistance and contribution related to my work from $744,373,045$, , 141 -,084
administrators.

10) Necessary accommodation is offered for those who want to build a career (such as graduate school or in-service education).

684,073, 089

16) Necessary opportunities are offered in order for me to do my job well.

672 242, 150,412 -,118

15) School administrators collaborate with teachers.

672, 405, 026, 116, -,089

5) My attendance to professional development opportunities such

as open sessions, conferences, and panels is encouraged.

668, 002, 198 -,240 -,077

9) I am treated equally by my superiors.

,570, 443, 097, 252 -,101

11) The school has a proper setting for the activities of education and learning.

,553, 222, 184, 507 -,082

23) ) I get along well with my colleagues.

151 748, 093 -,035 -,053

18) I am pleased to be a member of this school.

418, 638, 276 -,035

22) I can make a healthy balance between home and work.

182, 620,080

27) There is trust issue among school personnel.*

-,221-,601, 056 -,094,

17) The salary I get negatively affects my productiveness at work.* -,013 -,192 -,733 -,222,181

7) The salary I get is enough to follow up with academic ,228,095, 709 $\quad$,,022,001 publications such as books and journals in my field.

21) I do not think the salary I get is enough for what I do for work.*

$-, 076,029-, 667-, 206-, 053$

26) I find the opportunities for my health rights sufficient.

,337, 102, 629, -000

12) The number of classrooms in my school is not enough for education and learning.*

$-, 011,050-, 033-, 756,008$

13) My school has satisfactory working conditions.

400 311, 614 -,070

8) The school I work at has healthy working conditions.

388, 312, 261 , 575 -,022

6) I do not have the privilege to make decisions about my work in school.*

$-, 107-, 012,012,060-, 759$

4) I do not have the opportunities to follow changes or updates about my work.*

,027 -,019 -,109,039 -,742

29) I cannot defend my rights freely at work. *

$-, 158-, 151,093-, 145-, 579$

14) I do not think I can utilize my abilities at work.*

$-, 090-, 277-, 249-, 297-, 407$

* Negative items

As it can be seen on table 4, QSWL scale is composed of five dimensions. According to this analysis, first factor has 9 statements; describes 20.61 percent of the variance; has a 4.95 eigenvalue; 
Ilgan, A., Ata, A., Zepeda, S. J., \& Ozu-Cengiz, O. (2014). Validity and reliability study of Quality of School Work Life (QSWL) scale. International Journal of Human Sciences, 11(2), 114-137. doi: 10.14687/ijhs.v11i2.2866

and its factor loadings vary between .55 and .76. Second factor has 4 statements; describes 11.48 percent of the variance; has a 2.75 eigenvalue; and its factor loadings vary between .60 and .75 . Third factor has 4 statements; describes 9.33 percent of the variance; has a 2.37 eigenvalue; and its factor loadings vary between .63 and .73 . Fourth factor has 3 statements; describes 9.33 percent of the variance; has a 2.34 eigenvalue; and its factor loadings vary between .58 and .76 . Fifth and the last factor has 4 statements; describes 7.32 percent of the variance; has a 1.76 eigenvalue; and its factor loadings vary between .41 and .76. The results suggest that QSWL scale describes a total of 58.62 percent variance.

First dimension is categorized as "administrative support and career development assistance" because it includes statements such as administrative behaviors, career opportunities for school teachers, and professional development assistance. Second dimension includes statements of getting along well, pleased to be a member of school, healthy balance between home and work, and trust issues among school personnel, thus it is categorized as "relations with colleagues and embracement of school." Third dimension is named as "decent and fair wages and benefits" because its statements are about wages and employee rights. Fourth dimension is categorized as "healthy work environment" because it is about schools' working conditions. The last dimension is categorized as "opportunities at work" because its statements are regarding opportunities that are given to teachers at work.

\section{Findings regarding CFA}

Analysis and fit index results from testing factor structure (model) based on the EFA results with CFA are discussed in this section. According to AFA results, the scale is best utilized when it has the five dimensions. Thus, DFA is also tested in five dimensions.

QSWL scale was utilized most appropriately with five dimensions as EFA results showed, and according to CFA results of QSWL scale, it was found that $\chi^{2}=838.88$ and $s d=247$. One of the model fit indexes is $\chi^{2}$ / sd (Marsh, Balla and McDonald, 1988), and this is 3.39 based on the DFA results. Kline (2005) suggested that for large samples, $\chi^{2} /$ sd ratio that is less than 3 corresponds to excellent fit; $\chi^{2}$ / sd ratio that is less than 5 corresponds to intermediate level fit. According to this, the 3.39 value is a proper result for the model, and $\chi^{2}$ value is responding to the sample (Şimşek, 2007), so other fit indexes should also be looked at. When other fit indexes were examined, the 
Ilgan, A., Ata, A., Zepeda, S. J., \& Ozu-Cengiz, O. (2014). Validity and reliability study of Quality of School Work Life (QSWL) scale. International Journal of Human Sciences, 11(2), 114-137. doi: 10.14687/ijhs.v11i2.2866

root mean square error of approximation (RMSEA) that is given in the path schema is .076 and the root mean square residual (RMR) is .089. It is possible to say that the .076 value of RMSEA represents an acceptable fit (Marsh, Hau, Wen, 2004), and the .089 value of RMR is also an acceptable number (McDonald ve Moon-Ho, 2002). As the fit indexes were further examined, it was found that the goodness of fit index (GFI) was .85 and the adjusted goodness of fit index (AGFI) was .82. Because a food fit requires a number greater than .90 for GFI and AGFI indexes (Şimşek, 2007), the model's .85 and .82 values in this study indicate a weak fit. For model's other fit indexes, the normed fit index (NFI) is .92; the non-normed fit index (NNFI) is .93; and the comparative fit index (CFI) is .94. It can be concluded that these values are the indicators of a sufficient fit (Sümer, 2000). Figure 1 below shows the path schema that demonstrates the relations between statements and factors regarding the five-dimension model of the QSWL scale. 


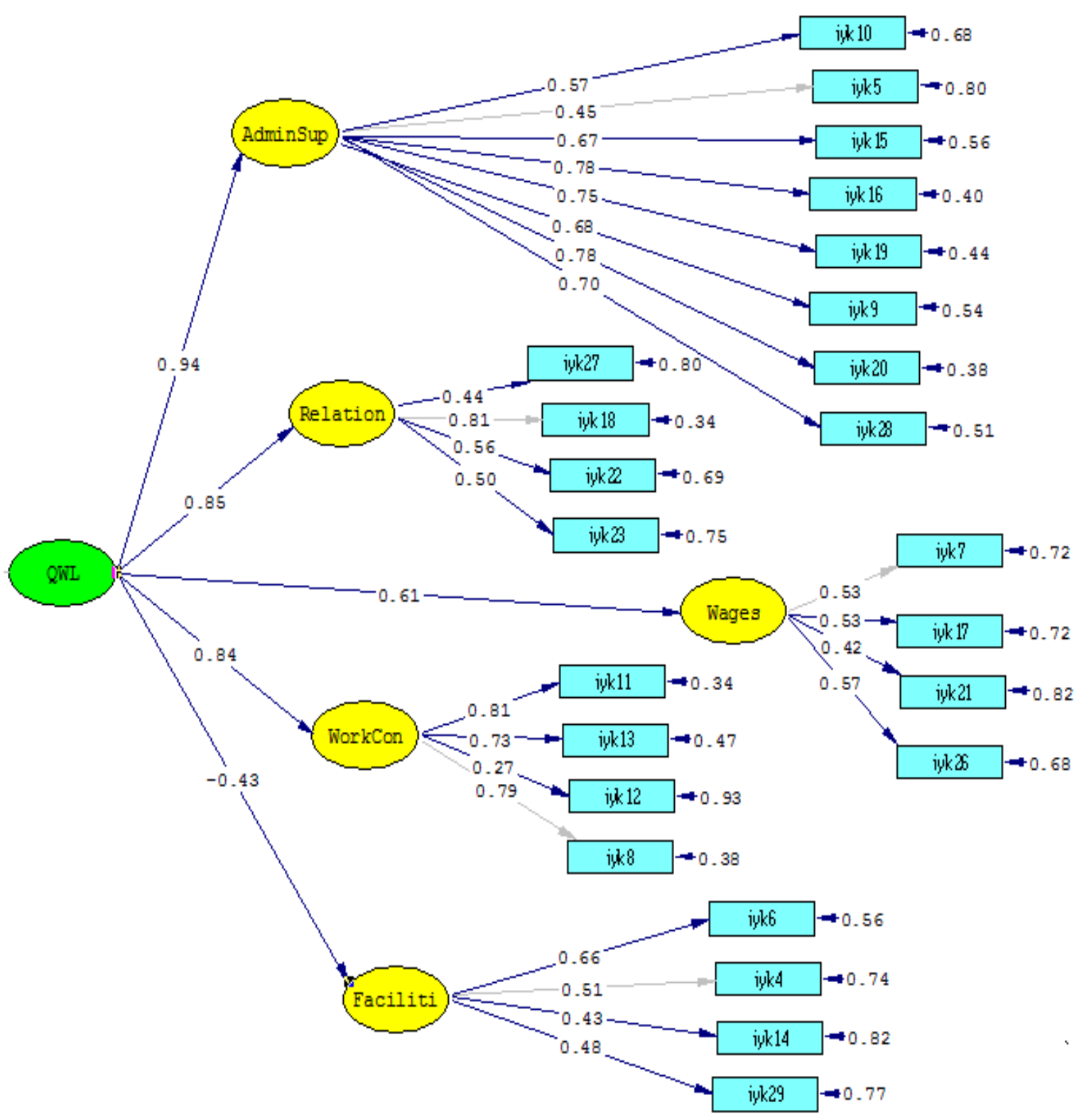

Chi-Square $=838.88, \mathrm{df}=247, \mathrm{P}-\mathrm{value}=0.00000, \mathrm{RMSEA}=0.076$

Figure 1. QSWL scale path schema

In figure 1, values on the one-way lines from factors (latent variable) to items (observed variable) show the factors' causative effect sizes on the items - in other words, factor loading values, and values on lines coming from left end towards items show error variances regarding the items. As they can be seen on the schema, error variances are between .34 and .93 , and they are at a reasonable and acceptable level. Items' factoring loadings are between .27 and .81 , and at a high 
Ilgan, A., Ata, A., Zepeda, S. J., \& Ozu-Cengiz, O. (2014). Validity and reliability study of Quality of School Work Life (QSWL) scale. International Journal of Human Sciences, 11(2), 114-137. doi: 10.14687/ijhs.v11i2.2866

level. The reason why the value on the line from QSWL to Opportunities at Work (Faciliti) is negative is because all of the items in this dimension are composed of negative statements.

Factor loadings, $\mathrm{t}$ and $\mathrm{R}^{2}$ results of the exploratory factor analysis regarding five-dimension CFA path schema of QSWL scale are presented in table 5.

Table 5. Factor-loadings, $t$ and $R^{2} V$ alues regarding Five-Dimension Path Schema of QSWL Scale

\begin{tabular}{|c|c|c|c|c|}
\hline \multirow[t]{2}{*}{ Dimensions } & \multirow[b]{2}{*}{ Item No } & \multicolumn{2}{|l|}{ Standardized } & \multirow[b]{2}{*}{$R^{2}$} \\
\hline & & $\begin{array}{l}\text { Factor loading } \\
\text { values }(\lambda)\end{array}$ & $t$ & \\
\hline \multirow{8}{*}{$\begin{array}{l}\text { Administrative } \\
\text { support and } \\
\text { career } \\
\text { development } \\
\text { assistance }\end{array}$} & 10 & 0.57 & $7.75^{*}$ & .32 \\
\hline & 5 & 0.45 & $7.62^{*}$ & .20 \\
\hline & 15 & 0.67 & $8.35^{*}$ & .44 \\
\hline & 16 & 0.78 & $8.85^{*}$ & .60 \\
\hline & 19 & 0.75 & $8.75^{*}$ & .56 \\
\hline & 9 & 0.68 & $8.42 *$ & .46 \\
\hline & 20 & 0.78 & $8.89 *$ & .62 \\
\hline & 28 & 0.70 & $8.53^{*}$ & .49 \\
\hline \multirow{4}{*}{$\begin{array}{l}\text { Relations with } \\
\text { colleagues and } \\
\text { embracement } \\
\text { of school }\end{array}$} & 27 & 0.44 & $8.27 *$ & .20 \\
\hline & 18 & 0.81 & $11.42^{*}$ & .66 \\
\hline & 22 & 0.56 & $10.38^{*}$ & .31 \\
\hline & 23 & 0.50 & $9.27 *$ & .25 \\
\hline \multirow{4}{*}{$\begin{array}{l}\text { Decent and fair } \\
\text { wages and } \\
\text { benefits }\end{array}$} & 7 & 0.53 & $5.42^{*}$ & .28 \\
\hline & 17 & 0.53 & $5.57^{*}$ & .28 \\
\hline & 21 & 0.42 & $5.77^{*}$ & .18 \\
\hline & 26 & 0.57 & $6.80 *$ & .32 \\
\hline \multirow{4}{*}{$\begin{array}{l}\text { Healthy work } \\
\text { environment }\end{array}$} & 11 & 0.81 & $16.34^{*}$ & .66 \\
\hline & 13 & 0.73 & $14.68^{*}$ & .53 \\
\hline & 12 & 0.27 & $5.04 *$ & .07 \\
\hline & 8 & 0.79 & $15.52^{*}$ & .62 \\
\hline \multirow{4}{*}{$\begin{array}{l}\text { Opportunities } \\
\text { at work }\end{array}$} & 6 & 0.66 & $6.53^{*}$ & .44 \\
\hline & 4 & 0.51 & $6.05^{*}$ & .26 \\
\hline & 14 & 0.43 & $5.61 *$ & .18 \\
\hline & 29 & 0.48 & $5.99 *$ & .23 \\
\hline
\end{tabular}

${ }^{*} p=, 000$ 
Ilgan, A., Ata, A., Zepeda, S. J., \& Ozu-Cengiz, O. (2014). Validity and reliability study of Quality of School Work Life (QSWL) scale. International Journal of Human Sciences, 11(2), 114-137. doi: 10.14687/ijhs.v11i2.2866

Standardized factor loading values $(\chi=$ Lambda) represent the correlation between observed variables and latent variables. High values of Lambda indicate a stronger relationship between latent and observed variables (Çokluk, Şekercioğlu, Büyüköztürk, 2010). Table 5 displays that items' factor loadings range between .27 and .81 , so it is accordingly possible to say that the factors have a high level of relevance with the items. Likewise, as can be seen from Table 5, $t$ values regarding the latent variables' state of describing the observed variables are statistically significant at .001 . Besides, the $\mathrm{R}^{2}$ values indicate how much of the explained variance in the observed variables stems from the latent variables, which is at a reasonable level of between .07 and .66. In the light of the given data, it is possible to say that EFA of five-dimension QSWL scale has validity at an acceptable level.

\section{Reliability and Internal Consistency Analysis of the QSWL scale}

Alpha reliability coefficient regarding the reliability of the sub-dimensions of QSWL scale and the difference between scores of the lower and upper $27 \%$ groups were also analyzed by using t-test for independent samples. Table 6 includes the QSWL scale and its factors' scores of the Cronbach's Alpha, lower and upper 27\% groups' average, standard deviation and t-test.

Table 6. QSWL scale and its factors' scores of the Cronbach's Alpha, lower and upper 27\% groups' average, standard deviation and t-test.

\begin{tabular}{|c|c|c|c|c|c|c|}
\hline \multirow[t]{2}{*}{ Factors } & \multirow{2}{*}{$\begin{array}{l}\text { Cronba } \\
\text { h’s } \\
\text { Alpha }\end{array}$} & \multicolumn{2}{|c|}{ Lower \% 27} & \multicolumn{2}{|c|}{ Upper \% 27} & \multirow{2}{*}{$\begin{array}{l}\text { t-test of the } \\
\text { lower and the } \\
\text { upper groups }\end{array}$} \\
\hline & & $\bar{x}$ & S & $\bar{x}$ & S & \\
\hline Composite QSWL scale & .87 & 62.06 & 5.75 & 89.62 & 5.47 & $50.54 *$ \\
\hline $\begin{array}{l}\text { Administrative support } \\
\text { and career development } \\
\text { assistance }\end{array}$ & .85 & 19,94 & 3,85 & 33,23 & 3,42 & $37.49 *$ \\
\hline $\begin{array}{l}\text { Relations with colleagues } \\
\text { and embracement of } \\
\text { school }\end{array}$ & .66 & 12,57 & 2,52 & 17,28 & 1,85 & $21.91 *$ \\
\hline $\begin{array}{l}\text { Decent and fair wages } \\
\text { and benefits }\end{array}$ & .63 & 8,66 & 2,78 & 13,13 & 2,87 & $16.26^{*}$ \\
\hline $\begin{array}{l}\text { Healthy } \\
\text { environment }\end{array}$ & .75 & 9,46 & 2,72 & 15,85 & 2,67 & $24.40^{*}$ \\
\hline Opportunities at work & .62 & 10,14 & 3,72 & 11,42 & 2,63 & $4.11 *$ \\
\hline
\end{tabular}

${ }^{*} p=, 000$; Lower and upper groups are composed of 212 participants. 
Ilgan, A., Ata, A., Zepeda, S. J., \& Ozu-Cengiz, O. (2014). Validity and reliability study of Quality of School Work Life (QSWL) scale. International Journal of Human Sciences, 11(2), 114-137. doi: 10.14687/ijhs.v11i2.2866

As it can be seen on table 6, the QSWL scale's Cronbach's Alpha coefficient value is .87. Its subdimensions' Cronbach's Alpha coefficient values are as follows: Administrative support and career development assistance: .85; relations with colleagues and embracement of school: .66; decent and fair wages and benefits: .63; healthy work environment: .75; and opportunities at work: .62. Besides, when the measurement instrument is considered as one dimension or multi-dimension, t-test values regarding the lower and upper 27\% groups' average score comparison are also as follows: Composite scale is 50.54 ; first dimension is 37.49 ; second dimension is 21.91 ; third dimension is 16.26; fourth dimension 24.4 ; and fifth dimension is 4.11 . These values are statistically significant ( $p$ $<.01)$.

\section{Correlation Matrix}

In order to examine the internal consistency of the measurement instrument, the correlation values, the mean and standard deviation values between the total scores of factors, among five dimensions, as well as in the case of the scale to be considered as a one-dimensional structure are given in Table 7.

Table 7. Correlation V alues between Factors, Mean, and the Standard Deviation

\begin{tabular}{|c|c|c|c|c|c|c|c|}
\hline \multirow{2}{*}{ Factors } & \multirow{2}{*}{$\bar{x}$} & \multirow{2}{*}{$S$} & \multicolumn{4}{|c|}{ Correlations between Factors } & \multirow[b]{2}{*}{ (5) } \\
\hline & & & (1) & (2) & (3) & (4) & \\
\hline Quality of Work Life (QSWL) & 78,30 & 11,26 & $.87^{* *}$ & $.71^{* *}$ & $.59^{* *}$ & $.74^{* *}$ & $.57^{* *}$ \\
\hline $\begin{array}{l}\text { Administrative support and } \\
\text { career development assist. (1) }\end{array}$ & 26,60 & 6,13 & & $.58 * *$ & $.37^{* *}$ & $.56^{* *}$ & $.33 * *$ \\
\hline $\begin{array}{l}\text { relations with colleagues and } \\
\text { embracement of school (2) }\end{array}$ & 15,02 & 2,77 & & & $.26^{* *}$ & $.44 * *$ & $.34 * *$ \\
\hline $\begin{array}{l}\text { decent and fair wages and } \\
\text { benefits (3) }\end{array}$ & 10,85 & 3,13 & & & & $.33 * *$ & $.23^{* *}$ \\
\hline healthy work environment (4) & 12,58 & 3,53 & & & & & $.26^{* *}$ \\
\hline opportunities at work $*(5)$ & 13,23 & 3,10 & & & & & \\
\hline
\end{tabular}

${ }^{* *} \mathrm{p} \leq .01 ;{ }^{*}$ recoded as positive

As can be seen from table 7, the correlation values between the QSWL and its sub-dimensions vary between .57 and .87 which are at intermediate and high levels. Accordingly, the highest correlation value with the composite QSWL scale is the sub-dimension "administrative support and the career development assistance" while the lowest correlation "healthy work environment" sub-dimension. 
Ilgan, A., Ata, A., Zepeda, S. J., \& Ozu-Cengiz, O. (2014). Validity and reliability study of Quality of School Work Life (QSWL) scale. International Journal of Human Sciences, 11(2), 114-137. doi: 10.14687/ijhs.v11i2.2866

The correlation values between the composite QSWL scale and its sub-dimensions, and the dimensions' correlation values with each other have all appeared to be significant at the level of .01.

As the average scores obtained of the measurement instrument(s) are examined, the highest score that can be obtained from the composite QSWL scale (24 items) is 120, the lowest score is 24, and the mean is $\bar{x}=78,3$. These results indicate that schools offer teachers medium level quality of work life according to teacher perception.

Moreover, sub-dimensions of the QSWL scale are examined, and the highest score that can be obtained from the first sub-dimension "administrative support and the career development assistance" ( 8 items) is 40 , the lowest score is 8 , and the mean is $(\mathrm{X}=26.6)$. The highest score that can be obtained from the second sub-dimension "relations with colleagues and embracement of school" (4 items) is 20 , the lowest score is 4 , and the mean is ( $\mathrm{X}=15.02)$. The highest score that can be obtained from the third sub-dimension "decent and fair wages and benefits" ( 4 items) is 20, the lowest score is 4 , and the mean is $(\mathrm{X}=10.85)$. The highest score that can be obtained from the fourth sub-dimension "healthy work environment" (4 items) is 20 , the lowest score is 4 , and the mean is $(X=12.58)$. The highest score that can be obtained from the fourth sub-dimension "opportunities at work" (4 items) is 20 , the lowest score is 4 , and the mean is ( $\mathrm{X}=13.23$ ). "Relations with colleagues and embracement of school" sub-dimension has the highest quality perception score while "decent and fair wages and benefits" sub-dimension relatively has the lowest quality perception score.

\section{Items Analysis}

In order to examine QSWL scale items' distinctiveness level for participants and their internal consistency, independent t-test scores regarding average differences between the upper and the lower $27 \%$ groups over a total score as well as corrected item-total correlations for each item are shown in table 8. 
Ilgan, A., Ata, A., Zepeda, S. J., \& Ozu-Cengiz, O. (2014). Validity and reliability study of Quality of School Work Life (QSWL) scale. International Journal of Human Sciences, 11(2), 114-137. doi: 10.14687/ijhs.v11i2.2866

Table 8. Results of the QSWL Scale Items Analysis

\begin{tabular}{|c|c|c|c|c|c|}
\hline Dimensions & Item no & $\bar{x}$ & $S D$ & $r$ & $t$ \\
\hline \multirow{8}{*}{$\begin{array}{l}\text { Administrative } \\
\text { support and the career } \\
\text { development } \\
\text { assistance }\end{array}$} & 10 & 3.31 & 1,23 & ,488 & $15.82 *$ \\
\hline & 5 & 3.08 & 1,16 &, 417 & $13.13^{*}$ \\
\hline & 15 & 3.63 & 1,05 & ,599 & $21.86^{*}$ \\
\hline & 16 & 3.27 & 1,03 & 681 & $23.46^{*}$ \\
\hline & 19 & 3.16 & 1,06 &, 700 & $23.13^{*}$ \\
\hline & 9 & 3.63 & 1,14 &, 574 & $19.75^{*}$ \\
\hline & 20 & 3.56 & 1,02 & ,702 & $22.23^{*}$ \\
\hline & 28 & 2.97 & 98 & ,644 & $19.73^{*}$ \\
\hline \multirow{4}{*}{$\begin{array}{l}\text { Relations } \\
\text { colleagues } \\
\text { embracement } \\
\text { school }\end{array}$} & 27 & 3,40 & 1,18 & ,383 & $11.89 *$ \\
\hline & 18 & 3,81 & 1,03 & ,462 & $21.12^{*}$ \\
\hline & 22 & 3,64 & ,96 & ,487 & $11.83^{*}$ \\
\hline & 23 & 4,17 &, 79 & ,446 & $9.30^{*}$ \\
\hline \multirow{4}{*}{$\begin{array}{l}\text { Decent and fair wages } \\
\text { and benefits }\end{array}$} & 7 & 2,48 & 1,16 & ,469 & $11.61 *$ \\
\hline & 17 & 3,04 & 1,23 & ,485 & $9.91 *$ \\
\hline & 21 & 2,36 & 1,24 & ,386 & $7.49 *$ \\
\hline & 26 & 2,97 & 1,13 & ,422 & $11.90 *$ \\
\hline \multirow{4}{*}{$\begin{array}{l}\text { Healthy } \\
\text { environment }\end{array}$} & 11 & 3,29 & 1,05 & ,672 & $21.75^{*}$ \\
\hline & 13 & 3,11 & 1,08 & ,635 & $19.54 *$ \\
\hline & 12 & 3,03 & 1,35 & ,335 & $7.92^{*}$ \\
\hline & 8 & 3,14 & 1,15 & ,626 & $23.60 *$ \\
\hline \multirow{4}{*}{ Opportunities at work } & 6 & $2,52^{1} / 3.46^{2}$ & $1,13 / 1.41$ & ,464 & $2.93^{*}$ \\
\hline & 4 & $2,52^{1} / 3.45^{2}$ & $1,05 / 1.07$ &, 377 & $3.03^{*}$ \\
\hline & 14 & $2,92^{1} / 3.08^{2}$ & $1,16 / 1.16$ & ,311 & $4.93^{*}$ \\
\hline & 29 & $2,75^{1} / 3.24^{2}$ & $1,21 / 1.21$ & ,386 & $3.16^{*}$ \\
\hline
\end{tabular}

$* \mathrm{p}=.000 ;{ }^{1}$ Negative item $;{ }^{2}$ recoded as positive

r: corrected item-total correlation values

t: t-test scores regarding differences per each item between the upper and the lower $27 \%$ groups of the measurement.

$\mathrm{n}_{1=} \mathrm{n}_{2}=$ groups of 212 participants.

As can be seen from Table 8, the corrected item-total correlation values range between .31 and .70. Results show that item-total correlation values are at a reasonable level, and that the items are relevant with the total measurement scores at a reasonable level. T-test scores regarding differences 
Ilgan, A., Ata, A., Zepeda, S. J., \& Ozu-Cengiz, O. (2014). Validity and reliability study of Quality of School Work Life (QSWL) scale. International Journal of Human Sciences, 11(2), 114-137. doi: 10.14687/ijhs.v11i2.2866

per each item between the upper and the lower $27 \%$ groups of the measurement range between 3.16 and 23.6. All item values are statistically significant $(\mathrm{p} \leq .000)$, and the arithmetic means of the items are between 2.48 and 4.17 .

\section{Results and Discussion}

When considered in a school setting, Quality of Work Life represents the appropriateness level of work life conditions of teachers in schools. In this context, QSWL needs to cover some components such as proper administrative practices towards employees, wages, health care, security, human relations, utilizing one's skills at work, and improvement of conditions. In this research, certain studies were conducted to develop a instrument by the help of data collected from teachers that will describe the appropriateness level of teachers' work life conditions, and the analyses regarding the validity and the reliability of the instrument are presented.

The draft instrument was initially developed based on the literature review and the interviews with 15 teachers, and a pilot-study with a considerable number of teachers was conducted after the draft instrument was refined with the experts' judgments. Exploratory factor analysis was used to revise the instrument, and confirmatory factor analysis was used to verify the revised instrument. The instrument had a total number of 30 statements, and 22 of them were positive and 8 were negative. Alpha factor analysis of the instrument revealed that 6 statements were not effective because of various reasons, thus they were removed. After the vertical rotation by Varimax method was used, the measurement instrument came out to be of five dimensions as followed: 1) Administrative support and career development assistance, 2) relations with colleagues and embracement of school, 3) decent and fair wages and benefits, 4) healthy work environment and 5) opportunities at work. These five dimensions explain a total 58.62 percent of variance, and their factor loadings range between .41 and .76. It is possible to say that the variance percentage is at a reasonable and acceptable level in social sciences.

The model/factor structure that was shaped with the exploratory factor analysis was retested and verified by the confirmatory factor analysis. Fit index results of the confirmatory factor analysis show that $\chi^{2}$ / sd ratio is reasonable; the root mean square error of approximation and the root mean square residual are acceptable; the goodness of fit index and the adjusted goodness of fit index are weak; the normed fit index, the non-normed fit index and the comparative fit index have 
Ilgan, A., Ata, A., Zepeda, S. J., \& Ozu-Cengiz, O. (2014). Validity and reliability study of Quality of School Work Life (QSWL) scale. International Journal of Human Sciences, 11(2), 114-137. doi: 10.14687/ijhs.v11i2.2866

acceptable values. It also showed that items' factoring loadings are between .27 and .81 , and at a high level; and t values regarding the latent variables' state of describing the observed variables are statistically significant at .001.

Composite QSWL scale's Cronbach's Alpha coefficient value is .87, and the dimensions' reliability coefficient values are as follows (in the above order): 1) .85; 2) .66; 3) .63; 4) .75; 5) .62. Additionally, the instruments' composite and sub-dimensions t-test values for the upper and the lower $27 \%$ groups are statistically significant at the .001 level. The corrected item-total correlation values range between .31 and .70 . Results show that item-total correlation values are at a reasonable level, and that the items are relevant with the total measurement scores at a reasonable.

The correlation values between the composite QSWL and its sub-dimensions vary between .57 and .87 which are at intermediate and high levels. The highest score that can be obtained from the composite QSWL scale (24 items) is 120 , the lowest score is 24 , and the mean is $\bar{x}=78,3$. These results indicate that schools offer teachers medium level quality of work life according to teacher perception. At the QSWL scale "relations with colleagues and embracement of school" subdimension has the highest quality perception score while "decent and fair wages and benefits" subdimension relatively has the lowest quality perception score level. By looking at the described situation and conditions, it can be inferred that teacher's QSWL at schools is not at a desired level, and it is important to reach past this level. This situation can affect teachers' work performance and motivation in addition to affecting students' learning in a negative way. Consequently, this newly developed scale is a valid and reliable instrument that serves to measure and describe schools' quality of work life.

\section{References}

Akdere, M. (2006). Improving quality of work-life: Implications for human resources. The Business Review, 6(1), 173-177.

Awosusi, O. (2010). Assessment of quality of working-life of nurses in two tertiary hospitals in Ekiti State, Nigeria. African Research Review, 4(2), 113-124.

Baleghizadeh, S., \& Gordani, Y. (2012). Motivation and quality of work life among secondary school efl teachers. Australian Journal of Teacher Education, 37(7), 30-42.

Beer, M., Spector, B., Lawrence, P.R., Mills, D.Q., \&Walton, R. E. (1985). Human Resource Management. New York: Free Press. 
Ilgan, A., Ata, A., Zepeda, S. J., \& Ozu-Cengiz, O. (2014). Validity and reliability study of Quality of School Work Life (QSWL) scale. International Journal of Human Sciences, 11(2), 114-137. doi: 10.14687/ijhs.v11i2.2866

Bindu, J., \& Yashika, S. (2014). Quality work life with special reference to academic sector. Research Journal of Management Science, 3(1), 14-17.

Çokluk, Ö., Şekercioğlu, G., \& Büyüköztürk, Ş. (2010). Sosyal bilimler için çok değģşkenli istatistikler. [Multivariate statistics for social sciences]. Ankara: Pegem Yayincllik

Danna, K., \& Griffin, R.W. (1999). Health and well-being in the workplace: A review and synthesis of the literature. Journal of Management, 25(3), 357-384.

Darabi, M., Mehdizadeh, A.H., Arefi, M., \& Ghasemi, A.A. (2013). Relationship between quality of work life and job satisfaction on school teachers in Kermanshah. Journal of Educational and Management Studies, 3(4), 508-513.

Davis, L.E., \& Cherns, A. (1975). The quality of working life: Problems, prospects, and the state of the art. New York: Free Press.

Day, C., Elliot, B., \& Kington, A. (2005). Reform, standards and teacher identity: Challenges of sustaining commitment. Teaching and teacher Education, 21(5), 563-577.

DeVellis, R. F. (2003). Scale development: Theory and applications (2nd ed.). Thousand Oaks, CA: Sage.

Emadzadeh, M.K., Khorasani, M., \& Nematizadeh, F. (2012). Assessing the quality of work life of primary school teachers in Isfahan City. Interdisciplinary Journal of Contemporary Research in Business, 3(9), 438-448.

Field, A. (2009). Discovering statistics using SPSS. (3 ${ }^{\text {rd }}$ Ed.). Los Angles: Sage Publication.

Friedman, D. E., Rimsky, C., \& Johnson, A. A.(1996). College and University Reference Guide Work/Family Programs. New York: Families and Work Institute.

Gayathiri, R., \& Ramakrishnan, L. (2013). Quality of work life - Linkage with job satisfaction and performance. International Journal of Business and Management Invention, 2(1), 1-8. Retrieved from www.ijbmi.org.

Grimm, L. G., \& Yarnold, P. R. (1995). Reading and understanding multivariate statistics. Washington, DC: American Psychological Association.

Goode, D.A. (1989). Quality of life, quality of work life. In W. E. Kiernan \& R. L. Schalock (Eds.), Economics, industry, and disability: A look ahead (pp. 337-349). Baltimore: Paul H. Brookes.

Gorsuch, R. L. (1983). Factor analysis (2nd ed.). Hillsdale, NJ: Lawrence Erlbaum.

Hannif, Z., Burgess, J., \& Connell, J. (2008). Call centeres and the quality of work life: Towards a research agenda. Journal of Industrail Relations, 50(2), 171-284.

Hsu, M.Y., \& Kernohan, G. (2005). Dimensions of hospital nurses' quality of working life. Nursing and Healthcare Management and Policy, 120-130. Blackwell Publishing Ltd.

Hutcheson, G., \& Sofroniou, N. (1999). The multivariate social scientist. London: Sage Publicaiton.

Jofreh, M., Yasini, A., Dehsorkhi, H.F., \& Hayat, A. (2013). The relationship between EFL teachers' quality of work life and job motivation. Middle-East Journal of Scientific Research, 13(3), 338-346.

Kahn, J. H. (2006). Factor analysis in counseling psychology research, training, and practice: Principles, advances, and applications. The Counseling Psychologist, 34, 684-718.

Kline, R. B. (2005). Principles and practice of structural equation modeling (2nd ed.). New York: Guilford.

Lu, H., While, A.E., \& Barriball, L.K. (2007). A model of job satisfaction of nurses: A reflection of nurses' working lives in mainland china. Journal of Advanced Nursing, 58(5), 468-479. 
Ilgan, A., Ata, A., Zepeda, S. J., \& Ozu-Cengiz, O. (2014). Validity and reliability study of Quality of School Work Life (QSWL) scale. International Journal of Human Sciences, 11(2), 114-137. doi: 10.14687/ijhs.v11i2.2866

Marsh, H. W., Balla, J. R., \& McDonald, R. P. (1988). Goodness-of-fit indexes in confirmatory factor analysis: The effect of sample size. Psychological Bulletin, 103, 391-410.

Marsh, H. W., Hau, K. T., \& Wen, Z. (2004). In search of golden rules: Comment on hypothesistesting approaches to setting cutoff values for fit indexes and dangers in overgeneralizing Hu and Bentler's (1999) findings. Structural Equation Modeling, 11, 320-341.

Martel, J.-P., \& Dupuis, G. (2006). Quality of work life: Theoretical and methodological problems, and presentation of a new model and measuring instrument. Social Indicators Research, 77(2), 333-368.

McDonal, R. P., \& Moon-Ho, R. H. (2002). Principles and practice in reporting structural equation analyses. Psybological Methods, 75(2), 420-435.

Mirvis, P. H., Lawler, E. E. (1984). Accounting for the quality of work life. Journal of Occupational Behavior, 5, 197-212.

Nadler, D. A., \& Lawler, E. E. (1983). Quality of work life: Perspectives and directions. Organizational Dynamics, 11(3), 20-30.

Robbins, S.P. (1989). Organizational behaviour: Concepts, controversies, applications. NJ: Prentice Hall.

Sirgy, M.J., Efraty, D., Siegel, P., \& Lee, D.-J. (2001). A new measure of quality of work life (qwl) based on need satisfaction and spillover theories. Social indicators research, 55(3), 241-302.

Spector, P.E. (1997). Job satisfaction: Application, assessment, causes, and consequences (Vol. 3): Sage.

Sümer, N. (2000). Yapısal eşitlik modelleri: Temel kavramlar ve örnek uygulamalar. [Structural equation modeling: Basic concepts and example applications]. Türk Psikoloji Yaz̨lar, 3(3), 49-74.

Şimşek, Ö. F. (2007). Yapısal eșitlik modellemesine giriș: Temel ilkeler ve Lisrel uygulamaları.. [Introduction to structural equation modeling: Basic concepts and Lisrel applications]. Ankara: Ekinoks Yayınevi.

Tabachnick, B. G., \& Fidell, L. S. (2001). Using multivariate statistics (4th ed.). New York: Harper \& Row.

Tsai, P.C.-F., Yen, Y.-F., Huang, L.-C., \& Huang, I.-C. (2007). A study on motivating employees' learning commitment in the post-downsizing era: Job satisfaction perspective. Journal of World Business, 42(2), 157-169.

Velicer,W. F., \& Fava, J. L. (1998). Effects of variable and subject sampling on factor pattern recovery. Psychological Methods, 3, 231-251.

Walton, R.E. (1973). Quality of working life: What is it? Sloan Management Review, 15(1), 11-21.

Worthington, R.L., \& Whittaker, T.A. (2006), "Scale development research: a content analysis and recommendations for best practices", The Counseling Psychologist, 34 (6), 806-838.

Zhao, X.W., Sun, T., QiuRu, C., Li, C., WiaoJian, D., Fan, L., \& Liu, Y. (2012). The impact of quality of worklife on job embeddedness and affective commitment and their coeffect on turnover intention of nurses. Journal of Clinical Nursing, 22, 780-788. 